\title{
ANALISIS PENGARUH KARAKTERISTIK DAN TATA KELOLA PERUSAHAAN TERHADAP PENGUNGKAPAN TANGGUNG JAWAB SOSIAL PERUSAHAAN DI INDONESIA
}

\author{
Sonia Kristina* dan Erna Wati* \\ *Jurusan Akuntansi, Fakultas Ekonomi \\ Universitas Internasional Batam \\ *Email: soniaxin@yahoo.com; ernawati_0342020@yahoo.com
}

\begin{abstract}
The purpose of this research is set out to investigate and discuss the influence of characteristics and corporate governance on social responsibility disclosures in Indonesian companies. Variables of the characteristics and corporate governance used in this research include government ownership, board of directors size, independent directors, company size, company age, liquidity, leverage and type of industry towards corporate social responsibility disclosure.

The total sample which met the criteria consists of 443 companies that have been listed on the Indonesian Stock Exchange from the 2013-2017 period. Where is determined by purposive sampling method. The data used in this research are the annual reports and financial reports of all companies which are published through the IDX website. The data analysis method used is panel data regression. This research was processed using SPSS 25 and Eviews 10 programs.

The results of this research showed that the variable profitability, company size and company age have a positive significant effect on corporate social responsibility disclosure. While the independent director's variables have a negative significant effect on corporate social responsibility disclosure. Moreover, the research confirmed that other variables such as liquidity, board of directors size, leverage, government ownership, and type of industry were not found to have a significant effect.
\end{abstract}

Keywords: Corporate characteristics, governance, corporate social responsibility disclosure.

\section{PENDAHULUAN}

Seiring dengan adanya dampak kerusakan lingkungan yang diakibatkan oleh kegiatan operasional perseroan maka dalam menanggapi masalah ini, perseroan mulai melaksanakan kontribusi kepada masyarakat sekitar melalui pengungkapan tanggung jawab sosial demi meningkatkan dukungan dan kepercayaan mereka (Handajani et al., 2014).

Makna dari pengungkapan tanggung jawab sosial ini sendiri adalah sebuah media yang mana perseroan dapat memberitahukan kepada masyarakat mengenai sejauh mana perseroan telah menyelesaikan masalah sosial dan lingkungan.
Praktik pengungkapan tanggung jawab sosial ini semakin dikenal di Indonesia dan bahkan hampir seluruh perseroan terbuka di Indonesia telah menerapkan praktik ini dalam laporan tahunan mereka. Hal ini dilatar belakangi oleh kasus-kasus yang pernah dialami di Indonesia, mulai dari kasus PT. Freeport di Papua yang merusak tanah ulayat, melanggar adat dan kesenjangan sosial ekonomi serta kasus PT. KHT-II, PT. ISIT dan PT. FST di Bandung yang menimbulkan pencemaran atau limbah (Gantyowati \& Agustine, 2017).

Pentingnya tingkat pengungkapan ini dapat dipengaruhi oleh berbagai faktor 
seperti karakteristik (Al-Gamrh \& AlDhamari, 2016; Naseem et al., 2017; Wuttichindanon, 2017) dan tata kelola perusahaan (Majeed et al., 2015; Arani, 2016; Sulub et al., 2018). Karakteristik perusahaan ini berkaitan erat dengan kegiatan sosial perusahaan, di mana perusahaan yang memiliki penghasilan yang tinggi dan sukses akan lebih banyak menerapkan program tanggung jawab sosial untuk memberikan kesan positif bagi publik (Muttakin et al., 2015). Tata kelola perusahaan juga berhubungan erat dengan kegiatan sosial. Dengan tata kelola perusahaan yang bagus cenderung akan meningkatkan transparansi informasi perusahaan melalui pengungkapan tanggung jawab sosial pada laporan tahunan mereka.

Adapun tujuan dalam penelitian ini adalah untuk menyelidiki apakah terdapat pengaruh karakteristik perusahaan (umur perusahaan, profitabilitas, ukuran perusahaan, leverage dan jenis industri) dan tata kelola perusahaan (kepemilikan pemerintah, direktur independen dan ukuran dewan) terhadap pengungkapan tanggung jawab sosial di Indonesia.

\section{KAJIAN LITERATUR DAN PENGEMBANGAN HIPOTESIS \\ Teori Pemangku Kepentingan}

Teori pemangku kepentingan menjelaskan bahwa perseroan tidak hanya memprioritaskan kepentingan sendiri namun perlu melakukan kontribusi kepada pemangku kepentingan. Teori ini berkaitan erat dengan sosial karena melalui pengungkapan tersebut dapat menjalin hubungan baik dengan pemangku kepentingan. Pemangku kepentingan terdiri dari pihak eksternal seperti karyawan atau pemasok dan pihak internal seperti komunitas atau publik (Wuttichindanon, 2017).

\section{Ukuran Dewan Direktur}

Ukuran dewan direktur merupakan kunci utama untuk memperlancar jalannya pengungkapan tanggung jawab sosial di suatu perusahaan karena segala keputusan mengenai program yang akan dijalankan suatu perusahaan perlu mendapatkan persetujuan dari dewan direktur (Esa \& Ghazali, 2012). Oleh karena itu, ukuran dewan direktur yang besar cenderung akan meningkatkan pengungkapan kegiatan sosial kepada publik. Beberapa peneliti seperti Lone et al. (2016), Dias et al. (2017), Wang (2017), Emmanuel et al. (2018), Zhuang et al. (2018) mendukung adanya pengaruh signifikan positif antara ukuran dewan direktur terhadap tingkat pengungkapan. Dari penjelasan tersebut, maka hipotesis yang diusulkan yaitu:

$\mathrm{H}_{1}$ : Ukuran dewan direktur berpengaruh signifikan positif terhadap pengungkapan tanggung jawab sosial.

\section{Direktur Independen}

Jumlah dari direktur independen yang banyak akan mengakibatkan tingkat keterbukaan informasi perseoran termasuk kegiatan sosial perseroan yang rendah (AlMoataz \& Hussainey, 2012). Hal ini didukung oleh Issa (2017) dan Sweiti (2017) yang membuktikan terdapat pengaruh signifikan negatif antara direktur independen dan pengungkapan tanggung jawab sosial. Dari penjelasan tersebut, maka hipotesis yang diusulkan, yaitu:

$\mathrm{H}_{2}$ : Direktur independen berpengaruh signifikan negatif terhadap pengungkapan tanggung jawab sosial.

\section{Kepemilikan Pemerintah}

Pemerintah merupakan institusi yang dipercaya oleh pubik yang akan menekankan perseroan untuk mengungkapkan informasi sosial tambahan dalam rangka untuk memenuhi harapan publik. Hal ini menunjukkan institusi pemerintah berperan penting terhadap pengungkapan kegiatan sosial (Wang et al., 2012). Hal ini searah dengan penelitian Al-Gamrh dan Al-Dhamari (2016), Habbash (2016), Wuttichindanon (2017) membuktikan adanya pengaruh signifikan positif. Dari penjelasan tersebut, maka hipotesis yang diusulkan, yaitu: 
$\mathrm{H}_{3}$ : Kepemilkan pemerintah berpengaruh signifikan positif terhadap pengungkapan tanggung jawab sosial.

\section{Ukuran Perusahaan}

Perseroan dengan kegiatan usaha yang besar cenderung akan memiliki kewajiban yang lebih besar termasuk melaporkan tanggung jawab sosial yang dilakukan untuk menambahkan citra positif dalam penyebaran kepada publik (Akrout \& Othman, 2013). Hal ini menandakan luas pengungkapan informasi sosial akan meningkat seiring dengan meningkatnya ukuran perusahaan. Hal ini dapat dukungan dari Issa (2017), Khalid et al. (2017), Syed dan Butt (2017), Mohammed (2018) yang menyebutkan ukuran perusahaan memiliki pengaruh signifikan positif terhadap tingkat pengungkapan. Dari penjelasan tersebut, maka hipotesis yang diusulkan, yaitu:

$\mathrm{H}_{4}$ : Ukuran perusahaan berpengaruh signifikan positif terhadap pengungkapan tanggung jawab sosial.

\section{Umur Perusahaan}

Umur perseroan yang semakin tua akan lebih eksis dan turut meningkatkan kepercayaan kepada investor. Hal ini searah dengan penelitian Al-Gamrh dan Al-Dhamari (2016) yang menyebutkan perseroan yang beroperasi lebih lama cenderung memiliki pengalaman yang lebih banyak dalam mempublikasikan pengungkapan informasi sosial disebabkan karena lebih menyadari atas nilai transparansi yang tinggi dapat membangun kesan positif perseroan. Hal ini konsisten dengan penelitian yang mengatakan adanya hubungan signifikan positif antara umur perusahaan dan tingkat pengungkapan (Basuony et al., 2014; Habbash, 2016; Elfeky \& Nasiri, 2017). Dari penjelasan tersebut, maka hipotesis yang diusulkan, yaitu:

$\begin{array}{rrr}\mathrm{H}_{5}: & \text { Umur perusahaan berpengaruh } \\ & \text { signifikan positif } & \text { terhadap } \\ & \text { pengungkapan tanggung jawab sosial. }\end{array}$

\section{Profitabilitas}

Perseroan yang mempunyai profitabilitas yang kuat maka perlu mengadakan praktik tanggung jawab sosial secara lebih luas untuk bisa melegitimasi keberadaan mereka. Konsisten dengan penelitian Abubakar (2017), Elshabasy (2017), Issa (2017) dan Nguyen et al. (2017) yang membuktikan adanya hubungan signifikan positif. Dari penjelasan tersebut, maka hipotesis yang diusulkan, yaitu:

$\mathrm{H}_{6}$ : Profitabilitas berpengaruh signifikan positif terhadap pengungkapan tanggung jawab sosial.

\section{Likuiditas}

Kuatnya nilai likuiditas suatu perseroan cenderung akan memberikan informasi sosial yang luas kepada publik. Hal ini dikonfirmasi dengan penelitian Gantyowati dan Agustine (2017) yang mengatakan adanya hubungan signifikan positif. Dari penjelasan tersebut, maka hipotesis yang diusulkan, yaitu:

$\mathrm{H}_{7}$ : Likuiditas berpengaruh signifikan positif terhadap pengungkapan tanggung jawab sosial.

\section{Leverage}

Perseroan dengan profil utang dan risiko kepailitan yang tinggi cenderung tidak mencurahkan biaya tambahan untuk isu-isu lingkungan perseroan (Uwuigbe \& Egbide, 2012). Sejalan dengan penelitian Habbash (2016), Swandari dan Sadikin (2016), Arora dan Soni (2017) membuktikan terdapat hubungan signifikan negatif. Dari penjelasan tersebut, maka hipotesis yang diusulkan, yaitu:

$\mathrm{H}_{8}$ : Leverage berpengaruh signifikan negatif terhadap pengungkapan tanggung jawab sosial.

\section{Jenis Industri}

Perseroan dengan bidang industri pertambangan ataupun manufaktur yang memiliki dampak kerusakan lingkungan yang besar cenderung akan mengungkapkan kegiatan sosial dan 
lingkungan lebih luas dibandingkan perseroan dengan bidang industri lainnya seperti perbankan, properti, konstruksi dan tekstil (Tan et al., 2016). Dikonfirmasi oleh Dias et al. (2017), Dyduch dan Krasodomska (2017), Syed dan Butt (2017) membuktikan terdapat pengaruh signifikan positif. Dari penjelasan tersebut, maka hipotesis yang diusulkan, yaitu:

$\mathrm{H}_{9}$ : Jenis industri berpengaruh signifikan positif terhadap pengungkapan tanggung jawab sosial.

\section{METODOLOGI PENELITIAN}

Penelitian ini diolah dari semua data perseoran di situs IDX dalam laporan tahunan dari periode 2013-2017 secara berturut-turut. Metode analisis data yang digunakan adalah metode purposive sampling, yaitu metode yang mempertimbangkan beberapa kriteria, meliputi: 1)perusahaan yang telah tercatat di BEI dengan horizon waktu dari tahun 2013-2017, 2)mempunyai data laporan keuangan perusahaan yang berhubungan dengan variabel penelitian secara lengkap dan sudah diaudit oleh KAP, dan 3)perusahaan yang mengungkapkan kegiatan tanggung jawab sosial di indeks laporan tahunan mereka.

\section{Variabel Dependen}

Variabel dependen yang ditetapkan dalam penelitian ini adalah pengungkapan tanggung jawab sosial. Pengungkapan ini dapat didefinisikan sebagai suatu tanggung jawab perusahaan untuk menciptakan manfaat sosial (Salusi et al., 2018). Pengukuran variabel ini menggunakan ISO 26000 yang dilakukan berdasarkan perhitungan ada atau tidaknya atribut pengungkapan yang tercantum dalam laporan tahunan perusahaan. Bila atribut telah diungkapkan maka diberikan skor 1 , sebaliknya bila atribut tidak diungkapkan maka diberikan skor 0 (Naser \& Hassan, 2013). Rumus perhitungan variabel ini menurut Habbash (2016), yaitu:

$\begin{aligned} & \text { Pengungkapan } \\ & \text { CSR }\end{aligned}=\frac{\text { Jumlah atribut CSR }}{37 \text { atribut CSR }}$

\section{Variabel Independen}

Variabel independen yang ditetapkan dalam penelitian ini adalah:

a. Ukuran Dewan Direktur

Dewan direktur merupakan organ perseroan yang bertanggung jawab dalam memimpin dan mengelola perseroan. Rumus perhitungan variabel ini menurut Dyduch dan Krasodomska (2017), yaitu:

$\begin{aligned} & \text { Ukuran dewan } \\ & \text { direktur }\end{aligned}=\begin{aligned} & \text { Jumlah direktur dalam } \\ & \text { perusahaan }\end{aligned}$

b. Direktur Independen

Direktur independen yang berperan dalam proses pemantauan perseroan. Rumus perhitungan variabel ini menurut Emmanuel et al. (2018), yaitu:

\begin{tabular}{|lc|}
$\begin{array}{l}\text { Direktur } \\
\text { independen }\end{array}$ & $=\begin{array}{c}\text { Jumlah direktur } \\
\text { independen }\end{array}$ \\
\hline & $\begin{array}{c}\text { Jumlah direktur dalam } \\
\text { perusahaan }\end{array}$ \\
\hline
\end{tabular}

c. Kepemilikan Pemerintah

Kepemilikan pemerintah adalah persentase saham perusahaan yang dimiliki oleh pihak pemerintah. Rumus perhitungan variabel ini menurut Muttakin et al. (2015), yaitu:

$\begin{aligned} & \text { Kepemilikan } \\ & \text { pemerintah }\end{aligned}=\frac{\begin{array}{c}\text { Jumlah saham yang } \\ \text { diperoleh pemerintah }\end{array}}{\begin{array}{c}\text { Jumlah saham yang } \\ \text { beredar }\end{array}}$

d. Ukuran Perusahaan

Ukuran perusahaan diartikan sebagai proporsi dalam mengukur besar atau kecilnya sebuah perseroan. Rumus perhitungan variabel ini menurut Niresh dan Silva (2018), yaitu:

$\begin{aligned} & \text { Ukuran } \\ & \text { perusahaan }\end{aligned}=\begin{aligned} & \text { Logaritma natural dari } \\ & \text { total aset }\end{aligned}$

e. Umur Perusahaan

Umur perusahaan menunjukkan lama sebuah perseroan berdiri, bertahan dan berkembang. Rumus perhitungan variabel ini menurut Wuttichindanon (2017), antara lain:

$\begin{aligned} & \text { Umur } \\ & \text { perusahaan }\end{aligned}=\begin{aligned} & \text { Jumlah tahun penelitian } \\ & \text { dikurangi tahun berdiri }\end{aligned}$


f. Profitabilitas

Profitabilitas diartikan sebagai indikator kinerja perusahaan dalam mengelola asetnya (Elshabasy, 2017). Rumus perhitungan variabel ini menurut Arani (2016), antara lain:

Profitabilitas $=\frac{\text { Laba bersih setelah pajak }}{\text { Total aset }}$

\section{g. Likuiditas}

Likuiditas diartikan sebagai proporsi yang mengindikasikan kinerja perusahaan dalam mendanai liabilitas lancar. Rumus perhitungan variabel ini menurut Nguyen et al. (2015), yaitu:

Likuiditas $=\frac{\text { Aset lancar }}{\text { Liabilitas lancar }}$

h. Leverage

Leverage didefinisikan sebagai indikator untuk mengukur sejauh mana ketergantungan perseroan terhadap pinjaman luar. Rumus perhitungan variabel ini menurut Umobong dan Agburuga (2018), yaitu:

Leverage $=\frac{\text { Total liabilitas }}{\text { Total aset }}$

\section{i. Jenis Industri}

Jenis industri menunjukkan di mana perusahaan tersebut digolongkan ke dalam kelompok industri yang sesuai dengan bidang usahanya. Rumus perhitungan variabel ini menurut Al-Gamrh dan AlDhamari (2016), yaitu:

$\begin{array}{ll}=1 & \text { Jika tergolong manufaktur dan } \\ & \text { pertambangan } \\ =0 & \text { Jika tergolong non-manufaktur dan } \\ \text { non-pertambangan }\end{array}$

\section{HASIL PENELITIAN Statistik Deskriptif}

Tabel 1

Hasil Uji Statistik Deskriptif

\begin{tabular}{|l|c|r|r|r|r|}
\hline \multicolumn{1}{|c|}{ Variabel } & N & \multicolumn{1}{c|}{ Minimum } & Maksimum & \multicolumn{1}{c|}{ Rata-rata } & Std. Deviasi \\
\hline Pengungkapan tanggung jawab sosial & 2111 & 0,027027 & 0,810811 & 0,329189 & 0,166406 \\
perusahaan & & & & \\
Ukuran dewan direktur & 2111 & 2 & 16 & 4,821412 & 2,065248 \\
Direktur independen & 2111 & 0,000000 & 1,000000 & 0,150572 & 0,152363 \\
Kepemilikan pemerintah & 2111 & 0,000000 & 0,900252 & 0,033574 & 0,143435 \\
Ukuran perusahaan & 2111 & 22,34878 & 34,65767 & 28,73328 & 1,856088 \\
Umur perusahaan & 2111 & 4 & 106 & 32,53529 & 15,53442 \\
Profitabilitas & 2111 & 0,000000 & 2,192031 & 0,049961 & 0,100750 \\
Likuiditas & 2111 & 0,004442 & 377,7900 & 4,796387 & 20,90175 \\
Leverage & 2111 & 0,000111 & 16,83442 & 0,596804 & 0,841701 \\
\hline
\end{tabular}

Note *: N= Jumlah Sampel

Sumber: Data penelitian diolah (2019)

Tabel 1 menunjukkan tingkat pengungkapan di Indonesia dengan nilai rata-rata $32,92 \%$, nilai minimum $2,7 \%$ dan maksimum $81,08 \%$ ini termasuk golongan yang cukup rendah bila dibandingkan dengan Malaysia dengan nilai rata-rata $85 \%$, nilai minimum $76 \%$, dan maksimum 93\% (Sallehudin, 2016). Namun, dinilai lebih tinggi bila dibandingkan dengan Arab Saudi yang memiliki nilai rata-rata pengungkapan $11,25 \%$ dengan minimum $0,79 \%$ dan maksimum $60,32 \%$ (Issa, 2017).
Dilihat dari variabel ukuran dewan direktur yang mempunyai nilai minimum 2 orang, maksimum 16 orang, dan nilai ratarata sekitar 5 orang. Hal ini dapat disimpulkan bahwa rata-rata perusahaan di Indonesia telah memenuhi syarat Peraturan Otoritas Jasa Keuangan Nomor 33/POJK.04/2014 Pasal 2 Ayat (1) yang menyebutkan bahwa direktur perseroan publik minimal terdiri dari 2 (dua) orang anggota direktur.

Nilai rata-rata pada variabel direktur independen adalah 15,06\% yang menyimpulkan direktur independen dalam 
perusahaan terbuka di Indonesia ini termasuk golongan cukup rendah daripada negara lain seperti Nigeria $86,15 \%$ (Isa \& Muhammad, 2015), Malaysia $41 \%$ (Ghabayen et al., 2016) dan Mesir 52,5\% (Elfeky \& Nasiri, 2017). Angka minimum adalah $0 \%$ yang berarti ada perusahaan yang tidak terdapat direktur independen, sedangkan angka maksimum adalah $100 \%$ yang berarti ada perusahaan yang mempunyai anggota direktur yang keseluruhannya merupakan pihak independen.

Angka minimum dan maksimum pada variabel kepemilikan pemerintah adalah $0 \%$ dan 90,03\%. Ini menandakan tidak semua perusahaan terbuka di Indonesia memiliki kepemilikan saham pemerintah dan terdapat juga perusahaan yang hampir keseluruhan saham dimiliki oleh pihak pemerintah. Sementara, angka rata-rata adalah $3,36 \%$ yang berarti ratarata dalam pasar modal di Indonesia keterlibatan pihak pemerintah lebih sedikit daripada pihak swasta.

Variabel ukuran perusahaan ini diproksi dengan logaritma natural dari total aset. Di mana dengan menggunakan logaritma natural (ln), total aset akan disederhanakan tanpa mengubah proporsi dari nilai aset yang sebenarnya. Angka rata-rata pada variabel ini adalah sebesar ln 28,73328 atau setara dengan Rp. 3.010.959.756.965. Hal ini menandakan perusahaan terbuka di Indonesia telah memenuhi peraturan Kep-00183/BEI/122018 Nomor I-A yang menwajibkan perusahaan mempunyai jumlah aset berwujud bersih minimum sebesar Rp. 100.000.000.000,- sebagai syarat pendaftaran perusahaan skala besar. Angka Minimum aset sebesar $\ln 22,34878$ atau setara dengan Rp. 5.081.024.411 yang dimiliki oleh PT Rimo International Lestari Tbk pada tahun 2013. Sedangkan, angka maksimum adalah sebesar ln 34,65767 atau setara dengan Rp. 1.126.248.442.000.000 yang dimiliki oleh PT Bank Rakyat Indonesia Tbk pada tahun 2017.
Dari variabel umur perusahaan menunjukkan angka minimum adalah 4 dan maksimum adalah 106. Ini menandakan perusahaan termuda di Indonesia berumur 4 tahun yang terdiri dari PT Cardig Aero Services Tbk dan PT Indofood CBP Sukses Makmur Tbk sejak tahun berdiri 2009 sampai dengan tahun penelitian 2013 dan umur tertua pada perusahaan di Indonesia adalah PT Bakrie Sumatera Plantations Tbk berumur 106 tahun yang dihitung sejak tahun berdiri 1911 sampai dengan tahun penelitian 2017. Angka rata-rata sebesar 32,54 menerangkan bahwa perseroan di Indonesia termasuk perseroan yang cukup berpengalaman dan mampu bersaing serta bertahan lama.

Perseroan di Indonesia rata-rata telah mempunyai kinerja baik dalam memperoleh laba dan telah memenuhi standar minimal Bank Indonesia yaitu sebesar 1,5\% yang terlampir di Surat Edaran Bank Indonesia No. 6/23/DPNP Tahun 2004. Hal ini dapat dilihat dari nilai rata-rata variabel profitabilitas yang menunjukkan 4,99\%. Sementara, terdapat juga perseroan yang tidak menghasilkan laba dari aset yang dimiliki pada periode tertentu, hal ini dapat diketahui dari angka terendah profitabilitas menunjukkan $0 \%$.

Nilai minimum untuk likuiditas sebesar $0,4442 \%$ artinya setiap Rp. 1 (satu rupiah) liabilitas lancar ditutupi dengan Rp. 0,004442 aset lancar. Hal ini dapat ditarik kesimpulan bahwa ada perusahaan di Indonesia masih belum mempunyai tingkat likuiditas yang bagus karena angka rasio kurang dari 1 (satu) atau $100 \%$ yang menandakan aset lancar masih belum dapat menutupi liabilitas lancarnya. Sementara, nilai rata-rata likuiditas sebesar $479,64 \%$ artinya setiap Rp. 1 liabilitas lancar ditutupi dengan Rp. 4,796387 aset lancar. Ini menandakan rata-rata perusahaan terbuka di Indonesia memiliki tingkat likuiditas yang bagus karena aset perusahaan telah dapat menjamin liabilitas lancarnya. 
Dilihat dari nilai maksimum leverage sebesar $1683,44 \%$ yang menandakan perseroan memiliki liabilitas tinggi. Hal ini menyimpulkan terdapat perseroan yang kemungkinan mempunyai tingkat risiko kegagalan dalam mengembalikan pinjaman yang tinggi karena aset perseroan sebesar 1683,44\% dibiayai dari liabilitasnya. Sebaliknya, nilai minimum leverage adalah $0,0111 \%$ yang menunjukkan terdapat perseroan yang memiliki tingkat risiko kepailitan yang rendah. Sementara, angka rata-rata adalah 0,596804 yang berarti rata-rata perseroan di Indonesia memiliki aset sebesar 59,68\% dibiayai dari liabilitasnya dan sisanya 40,32\% dibiayai dari ekuitas perseroan itu sendiri. Dengan demikian, rata-rata perusahaan di BEI masih dikategorikan dalam kondisi aman.

Tabel 2

Hasil Uji Statistik Deskriptif Variabel Dummy

\begin{tabular}{|c|l|c|c|}
\hline Variabel & \multicolumn{1}{|c|}{ Kategori } & Frekuensi & Persentase \\
\hline \multirow{2}{*}{ Jenis Industri } & $\begin{array}{l}\text { 0 = Non-Manufaktur dan Non-Pertambangan } \\
\text { 1 = Manufaktur dan Pertambangan } \\
\text { Total }\end{array}$ & 1168 & 55,3 \\
& $\frac{943}{2111}$ & $\frac{44,7}{100}$ \\
\hline
\end{tabular}

Sumber: Data penelitian diolah (2019)

Tabel 2 menunjukkan perseroan di Indonesia lebih banyak yang beroperasi di sektor non-manufaktur dan nonpertambangan yaitu sebesar $55,3 \%$ atau

1.168 data sampel daripada perusahaan yang beroperasi di sektor manufaktur dan pertambangan yaitu sebesar $44,7 \%$ atau 943 data sampel.

\section{Analisis Regresi Panel}

Tabel 3

Hasil Uji Chow

\begin{tabular}{|l|l|l|l|}
\hline \multicolumn{1}{|c|}{ Effect Test } & Statistic & d.f. & Prob. \\
\hline Cross-section Chi-square & 2235,651577 & 438 & 0,0000 \\
\hline
\end{tabular}

Note *: Korelasi signifikan pada $\geq 0,05$

Sumber: Data penelitian diolah (2019)

Tabel 4

Hasil Uji Hausman

\begin{tabular}{|l|c|c|c|}
\hline \multicolumn{1}{|c|}{ Test Summary } & Chi-Sq. Statistic & Chi-Sq. d.f. & Prob. \\
\hline Cross-section random & 82,037695 & 9 & 0,0000 \\
\hline
\end{tabular}

Note *: Korelasi signifikan pada $\geq 0,05$

Sumber: Data penelitian diolah (2019)

Regresi panel bertujuan untuk menetapkan model terbaik diantara pooled least squares, fixed effect model, dan random effect model. Penetapan model terbaik dapat dipilih melalui uji Chow dan uji Hausman dengan menggunakan program Eviews 10. Uji Chow dilakukan dengan memperhatikan nilai probabilitas pada cross-section chi-square. Bila nilai probabilitas lebih dari 0,05 maka model

terbaik adalah pooled least squares sedangkan bila nilai probabilitas kurang dari 0,05 maka model terbaik adalah fixed effect model. Tabel 3 merupakan hasil uji Chow dalam penelitian ini yang menerangkan nilai probabilitas sebesar 0,0000 , artinya model terbaik adalah fixed effect model. Sehingga perlu dilanjuti dengan melakukan uji Hausman. Uji Hausman dilakukan dengan 
memperhatikan nilai probabilitas pada cross-section random. Bila nilai probabilitas lebih dari 0,05 maka model terbaik adalah random effect model sedangkan bila nilai probabilitas kurang dari 0,05 maka model terbaik adalah fixed effect model. Tabel 4 merupakan hasil uji Hausman yang menerangkan bahwa nilai probabilitas sebesar 0,0000 yang berarti model terbaik adalah fixed effect model.

\section{Analisis Hipotesis}

\section{Tabel 5}

Hasil Uji F

\begin{tabular}{|c|c|c|c|}
\hline Variabel Dependen & F-statistic & Prob(F-statistic) & Kesimpulan \\
\hline Pengungkapan tanggung jawab sosial & 14,55148 & 0,000000 & Signifikan \\
\hline
\end{tabular}

Note $*$ : Korelasi signifikan pada $\geq 0,05$

**:Variabel independen: ukuran dewan direktur, dewan independen, kepemilikan pemerintah, ukuran perusahaan, umur perusahaan, profitabilitas, likuiditas, leverage dan jenis industri

Sumber: Data penelitian diolah (2019)

Tabel 5 merupakan hasil uji $\mathrm{F}$ menunjukkan nilai probabilitas sebesar 0,000000 yang kurang dari 0,05 yang berarti menjelaskan bahwa variabel independen yang digunakan pada penelitian ini secara simultan memiliki hubungan yang signifikan terhadap pengungkapan tanggung jawab sosial.

Tabel 6

Hasil Uji $t$

\begin{tabular}{|l|r|r|c|c|c|}
\hline \multicolumn{1}{|c|}{ Variabel } & Koefisien & t-Statistic & Prob. & Kesimpulan & Hipotesis \\
\hline (Konstanta) & $-0,560409$ & $-2,982745$ & 0,0029 & & \\
Ukuran dewan direktur & 0,000342 & 0,108316 & 0,9138 & Tidak Signifikan & Tidak Terbukti \\
Direktur independen & $-0,053140$ & $-2,299384$ & 0,0216 & Signifikan Negatif & Terbukti \\
Kepemilikan pemerintah & $-0,084325$ & $-0,872801$ & 0,3829 & Tidak Signifikan & Tidak Terbukti \\
Ukuran perusahaan & 0,016154 & 2,332834 & 0,0198 & Signifikan Positif & Terbukti \\
Umur perusahaan & 0,012862 & 8,375275 & 0,0000 & Signifikan Positif & Terbukti \\
Profitabilitas & 0,070049 & 2,471554 & 0,0136 & Signifikan Positif & Terbukti \\
Likuiditas & 20593701260 & 0,118439 & 0,9057 & Tidak Signifikan & Tidak Terbukti \\
Leverage & 0,003401 & 0,786369 & 0,4318 & Tidak Signifikan & Tidak Terbukti \\
Jenis Industri & 0,023611 & 0,352262 & 0,7247 & Tidak Signifikan & Tidak Terbukti \\
\hline
\end{tabular}

Note $*:$ Korelasi signifikan pada $\geq 0,05$

**: Variabel dependen: Pengungkapan tanggung jawab sosial

Sumber: Data penelitian diolah (2019)

Berdasarkan hasil uji $t$ maka persamaan regresi panel dapat dibentuk dalam model penelitian ini, yaitu:

$$
\begin{aligned}
\mathrm{Y}= & -0,560409+0,000342 \mathrm{X}_{1}- \\
& 0,053140 \mathrm{X}_{2}-0,084325 \mathrm{X}_{3}+ \\
& 0^{0} 016154 \mathrm{X}_{4}+0,012862 \mathrm{X}_{5}+ \\
& 0^{0} 070049 \mathrm{X}_{6}+20593701260 \mathrm{X}_{7} \\
& +0,003401 \mathrm{X}_{8}+0,023611 \mathrm{X}_{9}+ \\
& e
\end{aligned}
$$

Di mana:

$\mathrm{Y}=$ Pengungkapan tanggung jawab sosial

$\mathrm{X}_{1}=$ Ukuran dewan direktur

$\mathrm{X}_{2}=$ Direktur independen

$\mathrm{X}_{3}=$ Kepemilikan pemerintah
$\mathrm{X}_{4}=$ Ukuran perusahaan

$\mathrm{X}_{5}=$ Umur perusahaan

$\mathrm{X}_{6}=$ Profitabilitas

$\mathrm{X}_{7}=$ Likuiditas

$\mathrm{X}_{8}=$ Leverage

$\mathrm{X}_{9}=$ Jenis industri

$e=$ error

\section{$\mathrm{H}_{1}$ : Ukuran dewan direktur berpengaruh signifikan positif terhadap pengungkapan tanggung jawab sosial.}

Tabel 6 menerangkan nilai probabilitas variabel ukuran dewan direktur adalah 0,9138 yang melebihi 0,05 yang 
membuktikan variabel ini tidak memiliki pengaruh yang signifikan terhadap pengungkapan tanggung jawab sosial sehingga $\mathrm{H}_{1}$ ditolak. Hal ini menandakan ukuran dewan bukan berarti kualitas manajemen dari dewan itu sendiri sehingga efisiensi kerja dewan lebih penting dalam mengungkapan informasi sosial dibandingkan jumlah dewan (Uyar et al., 2013). Hasil penelitian ini didukung oleh beberapa peneliti seperti Sallehuddin (2016), Appah (2017), Dyduch dan Krasodomska (2017), Issa (2017), Ullah et al. (2018).

\section{$\mathrm{H}_{2}$ : Direktur independen berpengaruh signifikan negatif terhadap pengungkapan tanggung jawab sosial.}

Tabel 6 menerangkan nilai probabilitas variabel direktur independen adalah 0,0216 yang kurang dari 0,05 dan nilai koefisien sebesar $-0,053140$ yang membuktikan variabel ini berpengaruh signifikan negatif terhadap pengungkapan tanggung jawab sosial yang sesuai dengan hipotesis sehingga $\mathrm{H}_{2}$ diterima. Ini disebabkan karena direktur independen di Indonesia mungkin masih belum mandiri sehingga jumlah direktur independen di dewan yang semakin banyak akan menyebabkan pengawasan dewan menjadi kurang efektif (Al-Moataz \& Hussainey, 2012). Hasil penelitian konsisten dengan penelitian Issa (2017) dan Sweiti (2017).

\section{H3: Kepemilkan pemerintah} berpengaruh signifikan positif terhadap pengungkapan tanggung jawab sosial.

Tabel 6 menunjukkan nilai probabilitas kepemilikan pemerintah sebesar 0,3829 yang tidak ditemukan adanya pengaruh kepemilikan pemerintah terhadap pengungkapan tanggung jawab sosial sehingga $\mathrm{H}_{3}$ ditolak. Sesuai dengan peraturan UU No. 40 Tahun 2007 yang mewajibkan perseroan publik di Indonesia baik itu perseroan swasta maupun perseoran pemerintah untuk melaksanakan tanggung jawab sosial dan lingkungan. Hasil ini searah dengan penelitian Akrout dan Othman (2013), Mbekomize dan Dima (2013).

H4: Ukuran perusahaan berpengaruh signifikan positif terhadap pengungkapan tanggung jawab sosial.

Adanya hubungan signifikan positif pada variabel ukuran perusahaan terhadap tingkat pengungkapan yang telah dibuktikan pada hasil pengujian yang disajikan dalam Tabel 6 menerangkan bahwa nilai probabilitas sebesar 0,0198 dan nilai koefisien sebesar 0,016154 sehingga $\mathrm{H}_{4}$ diterima. Hasil penelitian ini didukung oleh Hieu dan Lan (2015), Jariya (2015), Razak (2015), Habbash (2016), Ohidoa et al. (2016), Dias et al. (2017), Elfeky dan Nasiri (2017), Khalid et al. (2017), Nguyen et al. (2017), Syed dan Butt (2017), Mohammed (2018).

\section{H5: Umur perusahaan berpengaruh signifikan positif terhadap pengungkapan tanggung jawab sosial.}

Tabel 6 menunjukkan nilai probabilitas variabel umur perusahaan sebesar 0,0000 dan nilai koefisien sebesar 0,012862 yang terbukti terdapat hubungan signifikan positif antara umur perusahaan dengan tingkat pengungkapan dan searah dengan hipotesis sehingga $\mathrm{H}_{5}$ diterima. Hasil ini sesuai dengan hasil penelitian yang dilakukan oleh Alturki (2014), Basuony et al. (2014), Habbash (2016), Elfeky dan Nasiri (2017), Nguyen et al. (2017).

\section{H6: Profitabilitas berpengaruh signifikan positif terhadap pengungkapan tanggung jawab sosial.}

Profitabilitas mempunyai signifikan positif dengan pengungkapan tanggung jawab sosial yang telah dibuktikan pada hasil pengujian yang disajikan dalam Tabel 6 menunjukkan nilai probabilitas sebesar 0,0136 dan konsisten dengan hipotesis $\mathrm{H}_{6}$ diterima. Hasil penelitian sejalan dengan penelitian Okegbe dan Egbunike (2016), Rosli et al. (2016), Swandari dan Sadikin (2016), Abubakar (2017), Elfeky dan 
Nasiri (2017), Elshabasy (2017), Gantyowati dan Agustine (2017), Issa (2017), Nguyen et al. (2017), Niresh dan Silva (2018), Saha (2018), Salisu et al. (2018).

\section{H7: Likuiditas berpengaruh signifikan positif terhadap pengungkapan tanggung jawab sosial.}

Tabel 6 menerangkan nilai probabilitas variabel likuiditas adalah 0,9057 yang lebih besar dari 0,05 yang tidak dapat membuktikan likuiditas memiliki pengaruh yang signifikan terhadap pengungkapan sehingga $\mathrm{H}_{7}$ ditolak. Hasil ini sejalan dengan penelitian Mensah (2012), Lan et al. (2013), Mohammed (2018). Disebabkan karena kurangnya perhatian dari pemangku kepentingan dalam memperhitungkan kualitas likuiditas entitas.

\section{H8: Leverage berpengaruh signifikan negatif terhadap pengungkapan tanggung jawab sosial.}

Tidak ditemukan adanya signifikan antara leverage dengan pengungkapan tanggung jawab sosial. Hal ini dapat dilihat dari nilai probabilitas yang sebesar 0,4318. Dengan demikian, $\mathrm{H}_{8}$ ditolak. Dengan adanya hubungan yang baik dengan kreditor maka kreditor mungkin tidak terlalu memperhatikan tingkat leverage. yang searah dengan penelitian Shehata et al. (2014), Dibia dan Onwuchekwa (2015), Razak (2015), Ohidoa et al. (2016), Abubakar (2017), Elshabasy (2017), Gantyowati dan Agustine (2017), Issa (2017), Mohammed (2018).

\section{H9: Jenis industri berpengaruh signifikan positif terhadap pengungkapan tanggung jawab sosial.}

Tabel 6 menerangkan nilai probabilitas variabel jenis industri adalah sebesar 0,7247 yang dibuktikan tidak terdapatnya pengaruh yang signifikan terhadap tingkat pengungkapan yang bertentangan dengan hipotesis sehingga $\mathrm{H}_{9}$ ditolak. Namun, hasil ini searah dengan penelitian Shehata et al. (2014), Dibia dan Onwuchekwa (2015), Habbash (2016), Rosli et al. (2016), Khalid et al. (2017).

Tabel 7

Hasil Uji Koefisien Determinasi

\begin{tabular}{|c|c|}
\hline Variabel Dependen & Adjusted R-squared \\
\hline Pengungkapan tanggung jawab sosial & 0,741659 \\
\hline Note *: Variabel independen: ukuran dewan direktur, dewan independen, kepemilikan pemerintah, ukuran \\
perusahaan, umur perusahaan, profitabilitas, likuiditas, leverage dan jenis industri
\end{tabular}

Sumber: Data penelitian diolah (2019)

Tabel 7 menunjukkan variabel independen yang digunakan dapat menerangkan pengungkapan tanggung jawab sosial sebesar 74,1659\%, sedangkan $25,8341 \%$ dijelaskan oleh variabel independen lain yang tidak terdapat dalam model penelitian ini seperti kepemilikan keluarga (Ohidoa et al., 2016), kepemilikan manajerial (Sallehuddin, 2016), komite audit (Dias et al., 2017), kepemilikan asing (Appah, 2017), rapat dewan (Naseem et al., 2017) dan lainnya.

\section{KESIMPULAN}

Laporan skripsi ini bertujuan untuk menyelidiki dan membahas pengaruh karakteristik dan tata kelola perusahaan terhadap pengungkapan tanggung jawab sosial. Hasil pengujian yang telah dilakukan peneliti menunjukkan ukuran perusahaan, profitabilitas dan umur perusahaan mempunyai hubungan signifikan positif terhadap pengungkapan tanggung jawab sosial sedangkan direktur independen mempunyai signifikan negatif terhadap pengungkapan tanggung jawab sosial. Variabel lainnya seperti ukuran 
dewan direktur, kepemilikan pemerintah, likuiditas, leverage, dan jenis industri tidak ditemukan adanya pengaruh signifikan.

\section{DAFTAR PUSTAKA}

Abubakar, A. A. (2017). Influence of firms attributes on environmental disclosure in listed brewery company in Nigeria. Research Journal of Finance and Accounting, 8(21), 31-35.

Akrout, M. M., \& Othman, H. B. (2013). A study of the determinants of corporate environmental disclosure in MENA emerging market. Journal of Reviews on Global Economics, 2, 46-59.

Al-Gamrh, B., \& Al-Dhamari, R. A. (2016). Firm characteristics and corporate social responsibility disclosure in Saudi Arabia. International Business Management, 10(18), 4283-4291.

Al-Moataz, E., \& Hussainey, K. (2012). Determinants of corporate governance disclosure in Saudi companies. Journal of Economics and Management, 5(1), 52-84.

Alturki, K. H. (2014). Voluntary disclosure by Saudi companies. Research Journal of Finance and Accounting, 5(20), 7794.

Appah, E. (2017). Corporate governance and corporate social responsibility of listed companies in Nigeria. Research Journal of Finance and Accounting, 8(14), 40-48.

Arani, M. H. Z. (2016). The effect of corporate governance mechanisms on social responsibility disclosure. Mediterranean Journal of Social Sciences, 7(4), 139-146.

Arora, A., \& Soni, T. K. (2017). Corporate social responsibility and firm characteristics: evidence from BSE 500. International Journal of Informaation, Business and Management, 9, 119-140.

Basuony, M. A. K., Elseidi, R. I., \& Mohamed, E. K. A. (2014). The impact of corporate social responsibility on firm performance: evidence form a MENA country. Corporate Ownership and Control, 12(1), 761-774.

Dias, A., Rodrigues, L. L., \& Craig, R. (2017). Corporate governance effects on social responsibility disclosures. Australasian Accounting, Business and Finance Journal, 11(2), 4-22.

Dibia, N. O., \& Onwuchekwa, J. C. (2015). Determinants of environmental disclosures in Nigeria: a case study of oil and gas companies. International Journal of Finance and Accounting, 4(3), 145-152.

Dyduch, J., \& Krasodomska, J. (2017). Determinants of corporate social responsibility disclosure: an empirical study of polish listed companies. Sustainability, 9(11), 1-24.

Elfeky, M. I., \& Nasiri, A. (2017). The determinants of voluntary disclosure in emerging market: the case of Egypt. Journal of Poverty, Investment and Development, 36, 1-12.

Elshabasy, Y. N. (2017). The impact of corporate characteristics on environmental information disclosure: an empirical study on the listed firms in Egypt. The Business and Management Review, 8(5), 181-191.

Emmanuel, O., Uwuigbe, U., Teddy, O., Tolulope, I., \& Eyitomi, G. A. (2018). Corporate diversity and corporate social environmental disclosure of listed manufacturing companies in Nigeria. Problems and Perspectives in Management, 16(3), 229-244.

Esa, E., \& Ghazali, N. A. M. (2012). Corporate social responsibility and corporate governance in Malaysian government-linked companies. Corporate Governance: The International Journal of Business in Society, 12(3), 292-305.

Gantyowati, E., \& Agustine, K. F. (2017). Firm's characteristics and CSR disclosure, Indonesia and Malaysia cases. Review of Integrative Business and Economics Reserarch, 6(3), 131145 . 
Ghabayen, M. A., Mohamad, N. R., \& Ahmad, N. (2016). Board characteristics and corporate social responsibility disclosure in the Jordanian banks. Corporate Board: Role, Duties and Composition, 12(1), 84-100.

Habbash, M. (2016). Corporate governance and corporate social responsibility disclosure: evidence from Saudi Arabia. Journal of Economic and Social Development, 3(1), 87-103.

Handajani, L., Subroto, B., Sutrisno, T., \& Saraswati, E. (2014). Does board diversity matter on corporate social disclosure? an Indonesian evidence. Journal of Economic and Substainable Development, 5(9), 8-16.

Hieu, P. D., \& Lan, D. T. H. (2015). Factors influencing the voluntary disclosure of Vietnamese listed companies. Journal of Modern Accounting and Auditing, 11(12), 656676.

Isa, M. A. \& Muhammad, S. (2015). The impact of board characteristics on corporate social responsibility disclosure: evidence from Nigerian food product firms. International Journal of Management Science and Business Administration, 1(12), 34-45.

Issa, A. I. F. (2017). The factors influencing corporate social responsibility disclosure in the kingdom of Saudi Arabia. Australian Journal of Basic and Applied Sciences, 11(10), 1-19.

Jariya, A. M. I. (2015). Determinants of environmental disclosure in annual reports of Sri Lankan listed manufacturing companies. Journal of Management, 12(1), 99-112.

Khalid, T. B., Kouhy, R., \& Hassan, A. (2017). The impact of corporate characteristics on social and environmental disclosure (CSED): the case of Jordan. Journal of Accounting and Auditing: Research \& Practice, 128.
Lone, E. J., Ali, A., \& Khan, I. (2016). Corporate governance and corporate social responsibility disclosure: evidence from Pakistan. Corporate Governance: The International Journal of Business in Society, 16(5), 785-797.

Majeed, S., Aziz, T., \& Saleem, S. (2015). The effect of corporate governance elements on corporate social responsibility (CSR) disclosure: an empirical evidence from listed companies at KSE Pakistan. International Journal of Financial Studies, 3(4), 530-556.

Mbekomize, C., \& Dima, L. W. (2013). Social and environmental disclosure by parastatals and companies listed on the Botswana stock exchange. Journal of Management and Sustainability, 3(3), 66-75.

Mensah, B. K. A. (2012). Association between firm-specific characteristics and level of disclosure of financial information of rural banks in the Ashanti region of graha. Journal of Applied Finance and Banking, 2(1), 13.

Mohammed, S. D. (2018). Mandatory social and environmental disclosure: a performance evaluation of listed Nigerian oil and gas companies preand post-mandatory disclosure requirements. Journal of Finance and Accounting, 6(2), 56-68.

Muttakin, M. B., Khan, A., \& Subramaniam, N. (2015). Firm characteristics, board diversity and corporate social responsibility: evidence from Bangladesh. Pacific Accounting Review, 27(3), 353-372.

Muttakin, M. B., Khan, A., \& Subramaniam, N. (2015). Firm ownership and board characteristics: do they matter for corporate social responsibility disclosure in Indian company?. Sustainability Accounting, Management and Policy Journal, 6(2), 138-165. 
Naseem, M. A., Riaz, S., Rehman, R. U., Ikram, A., \& Malik, F. (2017). Impact of board characteristics on corporate social responsibility disclosure. Journal of Applied Business Research, 33(4), 801-808.

Naser, K., \& Hassan, Y. (2013). Determinants of corporate social responsibility reporting: evidence from an emerging economy. Journal of Contemporary Issues in Business Research, 2(3), 56-74.

Nguyen, B. T. N., Tran, H. T. T., Le, O. H., Nguyen, P. T., Trinh, T. H., \& Le, V. (2015). Association between corporate social responsibility disclosures and firm value - empirical evidence from Vietnam. International Journal of Accounting and Financial Reporting, 5(1), 212-228.

Nguyen, L. S., Tran, M. D., Nguyen, T. X. H., \& Le, Q. H. (2017). Factors affecting disclosure levels of environmental accounting information: the case of Vietnam. Accounting and Finance Research, 6(4), 255-264

Niresh, J. A., \& Silva, W. H. E. (2018). The nexus between corporate social responsibility disclosure and financial performance: evidence from the listed banks, finance and insurance companies in Sri Lanka. Accounting and Finance Research, 7(2), 65-82.

Ohidoa, T., Omokhudu, O. O., \& Oserogho, I. A. F. (2016). Determinants of environmental disclosure. International Journal of Advance Academic Research / Social and Management Sciences, 2(8), 4958.

Okegbe, T. O., \& Egbunike, F. C. (2016). Corporate social responsibility and financial performance of selected quoted companies in Nigeria. $N G$ Journal of Social Development, 5(4), 168-189.

Razak, R. A. (2015). Corporate social responsibility disclosure and its determinants in Saudi Arabia. Middle-
East Journal of Scientific Research, 23(10), 2388-2398.

Rosli, M. H., Fauzi, N. A., Azami, M. F. A. M., Mohd, F., \& Said, J. (2016). Company characteristics and corporate social responsibility disclosure of Malaysian listed companies. International Conference on Accounting Studies, 1(1), 69-75.

Saha, A. K. (2018). Relationship between corporate social responsibility performance and disclosure: commercial banks of Bangladesh. Social Responsibility Journal, 1-20.

Salisu, U., Sani, S., \& Lawan, J. U. (2018). Corporate social responsibility disclosure and the value of listed conglomerates firms in Nigeria. Asian Journal of Economics, Business and Accounting, 7(4), 1-8.

Sallehuddin, M. R. (2016). The impact of corporate governance on voluntary disclosure among public-listed companies in Malaysia. e-Academia Journal UiTMT, 5(2), 48-57.

Shehata, N. F., Dahawy, K., \& Ismail, T. (2014). The relationship between firm characteristics and mandatory disclosure level: when egyptian accounting standards were first adopted. Mustang Journal of Accounting and Finance, 5, 85-103.

Sulub, S., Salleh, Z., \& Hashim, H. A. (2018). A review of corporate governance and corporate social responsibility disclosure of islamic banks: a call for additional transparency. Journal of Sustainability Science and Management, 4, 147-158.

Swandari, F., \& Sadikin, A. (2016). The effect of ownership stucture, profitability, leverage, and firm size on corporate social responsibility (CSR). Binus Business Review, 7(3), 315-320.

Sweiti, I. M. (2017). On the influence of the board's financial education on voluntary disclosure: evidence from Saudi Arabia. International Journal of Advanced and Applied Sciences, 4(2), 128-133. 
Syed, M. A., \& Butt, S. A. (2017). Financial and non-financial determinants of corporate social responsibility: empirical evidence from Pakistan. Social Responsibility Journal, 13(4), 780-797.

Tan, A., Benni, D., \& Liani, W. (2016). Determinants of corporate social responsibility disclosure and investor reaction. International Journal of Economics and Financial Issues, 6(4), 11-17.

Ullah, A., Shah, S., \& Asif, M. (2018). The impact of corporate governance on voluntary disclosure: evidence from Pakistan. City University Research Journal, 8(2), 155-167.

Umobong, A., \& Agburuga, U. T. (2018). Financial performance and corporate social responsibility of quoted firms in Nigeria. International Journal of Innovative Social Sciences \& Humanities Research, 6(1), 14-30.

Uwigbe, W., \& Egbide, B. C. (2012). Corporate social responsibility disclosures in Nigeria: a study of listed financial and non-financial firms. Journal of Management and Sustainability, 2(1), 160-169.
Uyar, A., Kilic, M., \& Bayyurt, N. (2013). Association between firm characteristics and corporate voluntary disclosure: evidence from Turkish listed companies. Intangible Capital, 9(4), 1080-1112.

Wang, M. C. (2017). The relationship between firm characteristics and the disclosure of sustainability reporting. Sustainability, 9(4), 624.

Wang, P., Wang, F., Zhang, J., \& Yang, B. (2012). The effect of ultimate owner and regulation policy on corporate social responsibility information disclosure: evidence from China. African Journal of Business Management, 6(20), 6183-6193.

Wuttichindanon, S. (2017). Corporate social responsibility disclosure choices of report and its determinants: empirical evidence from firms listed on the stock exchange of Thailand. Kasetsart Journal of Social Sciences, 38(2), 156-162.

Zhuang, Y., Chang, X., \& Lee, Y. (2018). Board composition and corporate social responsibility performance: evidence from Chinese public firms. Sustainability, 10(8), 1-12. 